ship, I trekked to the base camp on Mount Everest, Nepal. While photographing Mount Everest from Mount Kala Pattar $(5500 \mathrm{~m})$, I realised that I might wish to climb Everest in the future. I was drawn to do this; it seemed as though it would be my fate.

In 2005, I travelled to Tibet and stayed at Rongbuk for a short while. From there, you can see Everest in all its magnificence. I knew then that I wanted to climb the great mountain, to help to prove to myself, society, and healthcare professionals that I should not have been written off from life and that we can overcome the severest problems and scale the greatest heights.

I travelled to Nepal again in March 2006, trekking to Mera Peak, a recognised and well used training ground for Everest. Sherpas provided mountaineering training, which I enjoyed very much. If I can secure funding for my 2007 expedition to Everest itself, I shall be climbing with Dorjee Sherpa, who has climbed Everest 19 times, and a team of sherpas that includes my friend Nuru Jangbu Sherpa. I will ensure that I am able to continue with my treatment throughout the expedition.

\section{Evaluation}

I have always accepted my diagnosis of paranoid schizophrenia. What I refuse to accept is the label and the fears and misconceptions that are attached to it. I feel strongly that it has been the world of psychiatry, not society, that has discriminated and showed the least understanding of my illness. Paranoid schizophrenia is a greatly misunderstood illness, and misunderstanding from society and professional carers is harming many people who are already in much pain.

When I was given the diagnosis, my psychiatrist told my nurse that I was one of the severest cases of schizophrenia she had come across. With that statement, I should not be doing the things in life I am trying to achieve, such as attempting to climb Mount Everest next year. It is a shame that I feel I have to spell out that I am a good person who has never intentionally harmed anyone. Like other people with mental illness, I am intelligent, caring, loving, and creative, and I strive to be a good human being who yearns for a good, equal life, full of all the opportunities that any decent, respectful person deserves.

Too often these opportunities are taken from people with schizophrenia, because of our illness and because of the misunderstanding of our illness, our needs, and who we really are. I believe that the great misunderstanding of my illness and the discrimination and poor treatment I have received have been shameful and should not be accepted in the United Kingdom today. It has to change.

Competing interests: None declared.

To find out more about Stuart Baker-Brown and his Everest challenge, visit www.onemansmountain.com.

(Accepted 21 August 2006)

doi $10.1136 / \mathrm{bmj} .38968 .608275 . \mathrm{AE}$

\section{Interactive case report}

\section{Fever of unknown origin}

This case was described on 2 and 9 September (BMJ 2006;333:484, 541). Debate on the patient's management continues on bmj.com (http://bmj.bmijournals.com/cri/eletters/333/ $7566 / 484)$. On 30 September we will publish the case outcome together with commentaries on the issues raised by the management and online discussion from relevant experts and the patient's parents.

doi 10.1136/bmj.38951.494028.68

\title{
A no-win situation
}

Having recently started in a new hospital as a medical registrar, I was keen to make a good impression. My first on call fell right in the middle of the busy winter period. Patients were coming at us from all directions, and queues were building up. As a further incentive to stay on top of things, the registrar on night duty, my relieving angel, was a friend of mine. I'd never worked with her before, and I certainly didn't want to leave lots of work behind.

Sleeves up and on with the job. As the hours passed, I rushed around reviewing patients and then, as I caught up with the workload, clerking patients, cannulating, taking observations, etc. By the time the 9 pm handover arrived, I was absolutely exhausted, mentally and physically, but-and this was the important bit-there were no patients waiting to be seen, clerked, or reviewed. Success!

I announced the good news to my colleague and stepped back waiting for the appreciation and admiration. She simply responded, "So, you've had a quiet day." I almost collapsed.

It was then that I realised that I was truly in a no-win situation. If I'd left lots of patients to be seen the natural conclusion would have been that we'd been slacking during the day and had probably been sitting around drinking cups of tea. Of course, when we'd done everything then it was presumed we'd not had many admissions.

Still, I suppose it is better to have tried and failed than never to have tried at all.

Anne Foley specialist registrar, St Helen's and Knowsley Hospitals,Liverpool (drafoley@hotmail.com)

We welcome articles up to 600 words on topics such as A memorable patient, A paper that changed my practice, My most unfortunate mistake, or any other piece conveying instruction, pathos, or humour. Please submit the article on http://submit.bmj.com Permission is needed from the patient or a relative if an identifiable patient is referred to. We also welcome contributions for "Endpieces," consisting of quotations of up to 80 words (but most are considerably shorter) from any source, ancient or modern, which have appealed to the reader. 